\title{
Feministic Images of Women In Shobha De's Novels
}

\author{
Dr.E.Bhavani \\ Assistant Professor In Englishkrishna Universitymachilipatnam.
}

\begin{abstract}
Shobha De is an eminent and most popular Indian woman writer in English. De is a gifted novelist with extraordinary ability to discuss very sensitive aspects of human life tactfully. It attempts to make comprehensive critical comments on her fiction with an emphasis on the image of woman portrayed in her novel. The way she narrates each and every aspect of human relationship in general and man-woman relationship in particular, is superb. De differs from other Indian novel writers in English. She is a writer who believes in very frank narration of incidents and absolute open-heartedness. Shobha De is essentially a feminist writer. Like Nayantara sahgal, she concentrates on women's problems and gives a new approach to them.
\end{abstract}

A socio-political movement which Feminism advocates involved active participation by women to demand for their rights. It can be considered movement which is fought against female oppression under patriarchy. There are various ways by which a woman can be victimized or we can say that victimization of woman can take place through various ways like caste, color, race, attitude towards motherhood, etc. The Feminist movement was actually started by white women who basically jailed from middle class in western Europe and North America. This trend accelerated in 1960's with cool right movement and the collapse of European colonialism in Africa, Caribbean parts of Latin America and South Asia. Third wave feminism advocate for equal rights for the girls and taking charge of their own Sexual fulfillment. The new generation of feminism embraces beauty and power of women's sexuality to achieve their needs.

They consider sexual pleasure human right. Many writers in India have talked of pleasure and its manifestation. The heroins in Shobha De's novel rebuild their lost fortunes; make all efforts to look glamorous by losing weight and spending money in massage parlors. They try to look and act differently from the conventional and traditional women. They love to fall in love with their looks by which they try to attract people. It gives them immense pleasure when people fall head to heels in love with them and they are least concerned about it.

As a feminist writer, Shobha De's novels raise a strong protest against the male-dominated Indian society where women are derived the freedom to act and live according to their will. In this fact changing world, the role of women in the society too, has been changing fast, affecting greatly the Sexual monograms and social norms prevalent in the society. Shobha De reacts against the male culture and strongly detests the marginalization of women. She is the first women to explore the world of urban women of higher social strata. De has worked for the complete emancipation of woman. She projects the ideas of liberating woman through self-realization. However, Shobha De's stories are real stories, still happening in real life. Human relation based on gender distinctions, masculine domination, women's predicament relating to tradition and modernity are all important issues. And Shobha De, through ordinary stories, brings out the reality of our world around us. In all her novels she represents the picture of a New-Woman.

Since the researcher seeks to explore and explicate overall images of women and their life style suppression etc., appeared in her novels, it is a fascination study from the Indian point of view. The emphasis is on the image of woman with critical comments regarding the new emerging woman of modern cosmopolitan India. She portrays a variety of women from the traditional, subjugated and marginalized the extremely modern and liberated women.

KeyWords:- Tradition, New-Woman, Self Realization, Feminism, Identity, Exploitation, Discrimation, Emancipation Tec.

Shobha De doesn't believe in describing her women characters as love slaves or mere helpmates at home. Shobha De as a writer tries to mirror or portray her feminist mindset while portraying women in her novel. A broader evaluation of her work reveals her protest against the good old image of women who can't live the way she wants to and do things the way she wants to. Women's in her novels are represented as sexually liberated and free thinking who have been termed as, "New Woman". She talked about the self-realization of women. The high class. Educated, sensible women became protagonist in her novels. These New class of women whose lives were not infested by problems dowry or poverty. These Indian w2omen lived a blessed life as far as material standards are concerned, but there was something wanting, some vacuum in their lives. These Women were facing the problems of identity. They show concern about basic human problems and to them 
woman is a mother, a wife, a daughter, a house wife a working woman and about all she is a woman. Their women are the victims of a male-dominated society. In her novels men are not always sinners or oppressors. She explores the problems of women through her novels. She has raised woman's issues and strove to reach to their solutions as well.

In all her writings De represent new morality, according to which woman is not to be taken as a mere toy, an object of lust and momentary pleasure, but man's equal and honored partner. Women character undoubtedly reveals their feminist ideology. She portrays a variety of women from the traditional, subjugated and marginalized to the extremely modern and liberated women. She explored the lives of bored house wives and their loveless rich husbands and family. Her novels mirror the life styles of the elite and the middle classes of urban world. The portrayal of the image of subjugated and marginalized women in Shobha De's novel : Socialite Evenings [1989], Second Thoughts [1996], Starry Nights [1992], Sisters [1992] have been studied with an emphasis on men's pride, incompatible marriage, traditional norms of behaviors and patriarchal social system as the real forces of the oppression and exploitation of women. She draws our attention to women's exploitation, decimation and emancipation. She constantly tries to shatter patriarchal hegemony and raises a voice of protest against male dominance. In Socialite Evening, the first novel of Shobha De. Is about the journey of a prominent Bombay Socialite Karuna, from a middle class girl to a self-sufficient woman. Making a feminist approach, the novel gives as the picture of the marginalization of the Indian women at the hands of their husbands. Socialite Evening is a novel that 5 presents the institutions of family and marriage existing in the wealthy class of the Indian Society. An enduring theme in the novel is the search for identity and selfhoods, Karuna suffers due to the callous and non responsive attitude of her husband. Her husband treats her as a mere object subjected to his will as a result there is a complete loss of her identity. Her entry in the glamorous world of modeling and friendship with Bunty are the act of rebellion. After marriage she established extra martial relationship with Krish revolts against her insensitive husband and finally divorces him. Similarly Anjali, a young Socialite, about suffers much because of her incompatible marriage and her husband's oppressive attitude, Here, Shobha De's attack is not against the individuals, it is against the system that favors men and causes womens subjugation and marginalization.

The novel Second Thoughts [1996] is a sad tale of Maya, and oppressed wife. She suffers from marital disharmony because her husband Rajan considers woman as a mere object. Though an engineer, Maya is not allowed to take up even a part time job. Instead her husband again and again remands her of tradition : It is due to Rajan's traditional attitude and feelings of superiority Maya feels herself trapped in a neglected and meaningless life. He never tried to find out the reason behind Maya's gloominess. He was under the assumption that providing four square meals was more than enough for her and she ought to be grateful for what he was doing for her. Even when Maya advances to him in bed, he snubbed by saying that he needed time for it. The entry of Nikhil brought new meaning to Mays's life. He was fourth floor neighbor and was a college going student, he may not be interested in studies but he had mastered the art of captivation women. Maya could immediately feel the difference Nikhil brought to her life. Nikhil filled Maya with the power abed pleasure that she was so much desperate about she had found meaning her novels one feels that she has tried to fight for the cause of women and brought out the aspect of sex because she feels that women are marginalized in terms of sex.

Shobha De's novels represent the new Indian woman's voice. A New Woman is in search of self-identity, seeking liberation in all walks of life, replacing the traditional image of Indian woman. The traditional image of Indian woman. The need for women to seek their identity is the message in her novels. On the contrary, she shows her contempt and dislike for their unethical and socially unacceptable behavior. This can be deducted from the ultimate activities and deviant behavior. In fact Shobha De advices her women to analyze their behavior and stop posing to be men. In the present scenario of gender discrimination, a study of her novels helps to widen and direct our thoughts to relevant problems affecting women in Indian society.

In the Indian tradition marriage is glorified as a holy union of man and woman. It is the turning point and the beginning of a new way of life. However, in Shobha De's novels all these ideas degrading marriage are shattered by her modern liberated women with marriage the other important issue that De's novels deal with sex. Sex to her women is no longer a dreaded and despised thing. Her women enjoys a great deal of sexual freedom. In Sisters, through Mikki's and Alisha, Shobha De shows how the concept of marriage and constancy in love has undergone a tremendous changes. Mikki's encounters with different men help her to develop in to an independent woman who at the cost of her individuality finally saves the Hiralal industries. Shobha De's woman breaks all sorts of taboos and feel liberated.

In Sultry Days, the novelist presents a group of modern women who, when ill-treated, turn rebellions and protest. Nisha's mother protests against her husband's affair with his Secretary. Sujatha is another woman who does not lead a life which is defined by her husband. She makes her own rules. She has both male and female lovers. Further, the get-together of six former school friends at Reema's house in Snapshots also reveals how the women are obsessed with sex and sensual enjoyment. They express their grievances against men in 
general and husband in particular. They break the social norms and moral codes. Most of the women in the novel, bored with their husbands, seek new relationship outside marriage and challenge the patriarchal system.

Being a woman, De is more interested in the predicaments of woman. She presents the vital reality and makes us awake of the miseries of women and injustice done to them by their counterparts in the patriarchal society. However, it is an important fact that though De's novels are crowded with female characters, the analysis of the novels reveals her focus is only on the women protagonists, and the other secondary character are simply mentioned. In her novels she mostly discuss only the metropolitan women where rural women do not find place in her novels. They are totally ignored. All her novels are the protest novels against the malidominated Indian society where women are denied the freedom of expression and action. As a result their oppression, expatiation and marginalization, they turn rebellious. Shobha De's novels repdresent the new Indian woman's voice. A New-Woman is in search of self-identity seeking liberation in all walks of life, replacing the tradition image of Indian woman. The need for women to seek their identity is the message in her novels.

[1] Ruth Robbins, Literary Feminism [London : Macmillam press Ltd., 2000]

[2] Shobha De, Speed post.

[3] S.P.Swain, "Shobha De's Socialite Evening - A Feminist study, Feminist English Literature.

[4] K.Meerabai, "Feminism as an Extention of Existentialism woman in Indian English Fiction". Indian women Novelists, ed. R.K. Dhawan. 